\title{
Analysis of mineral and ash contents in domestic commercial sauces
}

\author{
Hyun-Jeong Kim ${ }^{1}$, Young-Eun Kim ${ }^{1}$, Ji-Eun Kim ${ }^{1}$, Dong Won $\mathrm{Seo}^{2}$, \\ Byung Hee $\mathrm{Kim}^{3}$, Sam-Pin Lee ${ }^{1,4 *}$ \\ ${ }^{1}$ The Center for Traditional Microorganism Resources, Keimyung University, Daegu 42601, Korea \\ ${ }^{2}$ Department of Food Analysis, Korea Food Research Institute, Wanju 55365, Korea \\ ${ }^{3}$ Department of Food and Nutrition, Sookmyung University, Seoul 04310, Korea \\ ${ }^{4}$ Department of Food Science and Technology, Keimyung University, Daegu 42601, Korea
}

\section{국내 시판 소스류에 대한 무기질 및 회분의 함량 분석}

\author{
김현정 ${ }^{1} \cdot$ 김영은 1 - 김지은 ${ }^{1} \cdot$ 서동원 $^{2} \cdot$ 김병희 ${ }^{3}$ - 이삼빈 ${ }^{1,4 *}$ \\ ${ }^{1}$ 계명대학교 전통미생물자원개발 및 산업화연구센터, ${ }^{2}$ 한국식품연구원 식품분석센터, \\ ${ }^{3}$ 숙명여자대학교 식품영양학과, ${ }^{4}$ 계명대학교 식품가공학과
}

\begin{abstract}
To aid in the development of a food nutrient database, the ash and mineral contents of 26 kinds of commercial sauces were analyzed. The contents of $\mathrm{Na}, \mathrm{Ca}, \mathrm{K}, \mathrm{P}, \mathrm{Mg}, \mathrm{Fe}, \mathrm{Mn}, \mathrm{Zn}$, and $\mathrm{Cu}$ were analyzed using ICP-OES, while that of Se was analyzed using ICP-MS. The reliability of the analytical method for the analysis of minerals and ash was confirmed based on a control chart. The ash contents of the sauces ranged from 1.08 to $12.79 \mathrm{~g} / 100$ $\mathrm{g}$, with 'Gondeulenamulbab yangnyeomjang' showing the highest $\mathrm{Na}, \mathrm{K}, \mathrm{P}$, and ash contents. The Na contents of the sauces differed greatly from 272.68 to $4,336.56 \mathrm{mg} / 100 \mathrm{~g}$, with 'Gondeulenamulbab yangnyeomjang' $(4,336.56 \pm 67.34 \mathrm{mg} / 100 \mathrm{~g})$ exhibiting the highest $\mathrm{Na}$ content. The mineral content ranges of the sauces were 5.93 $108.36 \mathrm{mg} / 100 \mathrm{~g}$ for $\mathrm{Ca}, 51.74-448.76 \mathrm{mg} / 100 \mathrm{~g}$ for $\mathrm{K}, 7.81-115.95 \mathrm{mg} / 100 \mathrm{~g}$ for $\mathrm{P}$, and $2.69-74.45 \mathrm{mg} / 100$ $\mathrm{g}$ for Mg. The sauces also contained $2.14-1,162.73 \mu \mathrm{g} / 100 \mathrm{~g}$ of $\mathrm{Fe}, 7.57-609.21 \mu \mathrm{g} / 100 \mathrm{~g}$ of $\mathrm{Mn}, 3.38$ - 145.74 $\mu \mathrm{g} / 100 \mathrm{~g}$ of $\mathrm{Cu}$, and $1.51-156.78 \mu \mathrm{g} / 100 \mathrm{~g}$ of Se. These results can be utilized as a basic database for the nutritional contents of commercial sauces as well as for the development of new sauce products.
\end{abstract}

Key words : sauce, mineral, ash, data base

서 론

최근 우리나라의 식생활이 1-2인 가구 수 및 여성의 경제활동 증가로 인한 편의성 추구 등 라이프 스타일이 변화되어 조리식품 등의 간편식과 외식에 대한 수요가 점차 증가하고 있다. 특히 하나의 소스 만으로 음식이 완성 되는 간편 만능소스, 메뉴 특화형 간편 소스처럼 다양한 종류의 소스류에 대한 소비가 증가되고 있다.
2017년 국내 소스류의 생산액을 보면 2조 4,965억 원에 이르며, 2013년에 비해 $16.9 \%$ 가 증가하였고, 품목별로는 소 스 $63.0 \%$, 복합 조미식품 $31.9 \%$, 마요네즈 3.2\%, 토마토케첩 $1.9 \%$ 등의 순으로 소스류가 생산되어 소비되었고, 그 중 소스 의 소비 비중이 가장 큰 것으로 보고되었다(FAFFDC, 2018). 소스는 여러 가지 원료를 배합하여 음식물에 잘 어울려지도 록 한 조미료의 한 종류로, 맛과 색상을 부여하여 식욕을 증진시키고, 첨가되는 재료에 의해 영양가를 높일 수 있다

*Corresponding author. E-mail : splee@kmu.ac.kr, Phone : +82-53-580-5554, Fax : +82-53-580-6465

Received 06 September 2019; Revised 13 November 2019; Accepted 26 November 2019.

Copyright (c) The Korean Society of Food Preservation.

This is an Open Access article distributed under the terms of the Creative Commons Attribution Non-Commercial License (http://creativecommons.org/licenses/by-nc/4.0) which permits unrestricted non-commercial use, distribution, and reproduction in any medium, provided the original work is properly cited. 
(Choi, 2004).

일반적으로 소스는 야채류에 양념을 가열하여 혼합한 것과 여기에 각종 부산물을 기호에 따라 일정량 첨가하여 다양한 맛과 향을 내는 것으로 알려져 있다(Shahidi 등, 1989). 또한, 소스는 액체 또는 반유동상태의 조미료 형태 로 수천 종이 알려져 있으며(Kenneth, 1990; Choi, 1997), 그 중 칠리, 타바스코, 살사, 토마토케첩과 같은 소스류는 스테이크, 바비큐, 생선, fried chicken, 햄버거, 피자, 스파게 티, 튀김류, 샐러드 등 다양한 요리에 이용되고 있다(Gary, 1999). 특히 국내에서는 고추장, 된장, 간장 등을 이용한 발효양념장의 형태의 소스류가 제조되어 널리 유통되고 있으며, 고추나 마늘 같은 채소를 이용한 양념류(Choi 등, 2010)와 간장을 이용한 불고기, 갈비, 닭찜 소스나 고추장 을 이용한 비빔밥, 떡볶이 소스 등의 가공제품으로도 많이 제조되어 유통되고 있다(Lee와 Mun, 2012; Choi 등, 2013). 이처럼 소스류가 편리성과 다양성을 추구하는 현대인에 게 다양한 형태로 널리 보급되어 소비가 증가되고 있지만, 유통 중인 소스류에 대한 영양성분에 대한 분석 연구는 미흡한 편이다.

최근 젊은 성인의 경우, 가공식품으로 나트륨 섭취량의 $30 \%$ 가 공급되어 $(\mathrm{Kim}$ 등, 2016), 외식뿐 아니라 가공식품 을 통한 나트륨 섭취가 문제될 수 있는데(MOHW \& $\mathrm{KCDC}, 2015)$, 그 중 소스류는 자체 염도가 높고(Lee 등, 2010), 양념류보다 섭취량이 많아서 다량 섭취 시 나트륨 과잉에 대한 문제가 나타날 수 있다. 나트륨의 과잉섭취는 고혈압의 주요 원인이 되며, 심혈관계질환, 골다공증 등의 질병의 위험을 증가시키고 위암, 신장결석 등을 유발할 수 있어(Blaustein과 Hamlyn, 1983), 우리나라 국민의 일일 나트륨 섭취량에 대한 국가 차원의 관리가 필요한 영양소 라 할 수 있다. 또한, 인은 체내 칼슘 다음으로 많이 존재하 는 무기질로서, 골격구성, 체액의 평형유지, 에너지 대사 등에 관여하는 중요한 역할을 하지만, 육류, 어류, 난류, 우유 등의 식품 및 식품첨가물로서 가공식품에 다량 함유 되어(Lim, 2014) 최근에는 가공식품의 섭취 증가로 인한 인의 과잉 섭취가 문제되기도 하였다.

반면, 2016년 국민건강영양조사(MOHW \& KCDC, 2016)에 따르면 무기질 중 칼슘, 철 및 칼륨은 우리나라 국민이 부족하게 섭취하는 영양소로, 칼슘은 만성질환, 뼈 건강 등의 질환을 예방하기 위해서 충분한 섭취가 이루 어져야 하나 한국인의 전 연령대에서 섭취가 부족한 편이 었고, 철은 권장섭취량과 비교했을 때 12-29세 여성군에 서 섭취율이 낮고, 15 - 18세 남녀 청소년에서도 평균 필요 량보다 철의 섭취율이 낮았다. 또한, 칼륨은 나트륨의 흡수 를 억제하거나 배설을 촉진하는 생리기능에 따라 나트륨 의 과잉 섭취로 유발되는 고혈압에 대한 보호 작용을 하고, 나트륨/칼륨 $(\mathrm{Na} / \mathrm{K})$ 비율을 1 에 가깝게 낮추면 고혈압의
예방과 개선에 효과가 있으나(Hwang 등, 2017), 우리나라 국민의 칼륨 섭취량은 전 연령층에서 부족하다고 보고 (MOHW \& KCDC, 2016)되었다. 칼륨은 식품에 널리 함유 되어 있으나, 수세나 삶기 등 조리과정에서 상당량 손실되 므로 가공식품에 함유된 칼륨에 대한 직접적인 분석이 필요한 영양소라 할 수 있다.

망간은 골격에 존재하며, 열량영양소인 탄수화물, 단백 질, 지질 대사에 관여하며 철 흡수를 억제하고, 칼슘과 아연 등의 무기질의 과잉 섭취 시에는 망간의 체내 이용률 에 영향을 미치고, 다양한 식품에 함유되어 있으나 흡수율 이 낮고 섭취량의 변이가 커 망간 필요량을 추정하기 어렵 다(Greger, 1998). 또한, 미량 무기질인 셀레늄은 암 발생 예방 등(Jablonska 등, 2008)의 영양학적 중요성이 알려져 있으나, 한국인 섭취기준 설정에 필요한 자료들이 아직도 부족한 실정이다. 특히 우리나라 식품의 망간 및 셀레늄 함량에 대한 자료가 부족하여 이들 영양소의 섭취 실태를 파악하기 힘든 제한점을 가진다.

또한, 마그네슘은 비교적 견과류와 녹황색 채소 및 과일 에 많이 함유되어 있으나, 현대인들의 불규칙한 식습관으 로 인한 마그네슘 부족증이 보고(NIAS, 2018)되고 있고, 또한 아연과 구리의 이상적인 섭취비는 1 대 8 로 두 성분은 시소처럼 작용해 하나가 많으면 다른 쪽은 줄어드는 현상 이 발생하는데, 최근 식습관의 변화로 현미나 두부에 많이 든 아연의 섭취량은 줄고, 견과류나 조개류 등 일상적인 음식으로 구리를 쉽게 섭취하게 되어 이들 무기질의 균형 적인 섭취량에도 변화를 받고 있다(Choi 등, 2001; Kim 등, 2014).

이처럼 신진 대사나 성장에 필수적인 영양소인 무기질 은 인체에서 필요한 양은 아주 적지만, 부족하게 되면 정상 적인 신체 기능을 유지하는 데 문제가 생기고, 또한 과다 섭취하면 부작용을 초래하여 여러 문제가 발생될 수 있으 므로 우리가 평소 섭취하는 식품에 대한 무기질의 함량에 대한 정보 제공은 건강을 유지하고 질병을 예방하기 위해 서 중요하다.

따라서 우리가 흔히 섭취하고 있는 시판 소스류 26 종을 대상으로 무기질 및 회분 함량에 대한 정보를 제공하여 소비자들에게 이들 영양소 성분에 대한 올바른 이해를 돕고, 나아가 국민의 건강증진을 위한 기초자료로 제공하 고자 하였다.

\section{재료 및 방법}

\section{실험 재료}

본 연구에 사용된 시료는 국가 영양성분 데이터베이스 (DB) 구축을 위하여 국내에서 선호도와 섭취빈도가 높은 26 종의 소스류를 실험에 사용하였고, 시료는 숙명여자대 
학교 NLS 센터에서 균질 상태로 조제한 다음, $-20^{\circ} \mathrm{C}$ 이하 의 냉동 상태로 배송하였다. 시료는 제공받은 직후 $-20^{\circ} \mathrm{C}$ 의 냉동상태로 보관하면서 실험하기 전에 냉장고로 옮겨 24 시간 해동한 다음 회분 및 무기질의 함량 분석에 사용하 였다. 무기질의 표준시약은 AccuStandard Inc. (New Haven, CT, USA) 또는 Sigma-Aldrich Co.(St. Louis, MO, USA)에 서 구입하여 사용하였고, 추출에 사용된 용매는 normalgrade, 기기분석 시 사용된 용매는 분석용 특급시약인 Sigma-Aldrich Co.(St. Louis, MO, USA)을 사용하였다.

\section{무기질 분석}

무기질 함량은 균질화한 시료 일정량(약 $0.3-0.5 \mathrm{~g})$ 을 microwave 분해용기 $(100 \mathrm{~mL})$ 에 취하여 질산 $(70 \%) 8.0 \mathrm{~mL}$ 와 $\mathrm{H}_{2} \mathrm{O}_{2} 2 \mathrm{~mL}$ 를 가한 후, Microwave Digestion System (MARS6, CEM Co., Matthews, NC, USA)를 이용하여 1시간 이상 완전히 분해하였다. 이 분해물을 $50 \mathrm{~mL}$ 로 정용하고, 이를 적당량 희석하여 $\mathrm{Na}, \mathrm{K}, \mathrm{Ca}, \mathrm{P}, \mathrm{Mg}, \mathrm{Fe}, \mathrm{Zn}, \mathrm{Cu}$ 및 $\mathrm{Mn}$ 은 ICP-OES(Optima 7000DV, Perkin-Elmer, Shelton, CT, USA), Se은 ICP-MS(NexION300D, Perkin-Elmer, Shelton, CT, USA)로 분석하였으며, 그 조건은 Table 1 과 같다. 무기 질의 정량 분석을 위하여 각각의 무기질 standard $(\geq 99.0 \%$, AccuStandard Inc. New Haven, CT, USA)는 2\% 질산으로 희석하여 $0.1,1,5,10,50,100 \mathrm{mg} / \mathrm{kg}$ 의 농도별로 분석하여 검량선을 작성하고, $\mathrm{Se}$ 은 1-50 $\mu \mathrm{g} / \mathrm{kg}$ 의 농도에서 검량선 을 작성하여 각 시료의 무기질 함량을 환산하였다.

\section{회분 분석}

회분 함량은 직접 회화법으로 시료를 항량시킨 회화도
가니에 담은 후 전기로(J-FM3, JISICO, Seoul, Korea)에서 예비 탄화시킨 다음, $550-600^{\circ} \mathrm{C}$ 의 회화로에서 시료 전체 가 회백색으로 되도록 12 시간 이상 회화시켰다. 회화 후 $200^{\circ} \mathrm{C}$ 로 식힌 다음 데시케이터에서 방냉하고, 항량을 구하 여 시료 무게에 대한 백분율로 회분 함량을 나타내었다.

\section{분석품질관리}

무기질의 내부 분석품질관리는 분석품질관리도표 (Quality Control chart, QC 차트)를 통해 매회 분석 값에 대한 신뢰도를 확인하였다. 분석품질을 확인하기 위한 시 료로 시판조제분유(Imperial Deream XO, Namyang, Seoul, Korea)를 활용하였다. 매 분석 때마다 3 반복씩 분석을 진행 하여 각각의 평균값을 제시하고 관리상한선(Upper Control Line, UCL)과 관리하한선(Lower Control Line, LCL)을 설 정하였고, 조치상한선(Upper Action Line, UAL)과 조치하 한선(Lower Action Line, LAL)을 설정하였다. 관리상한선 과 관리하한선은 분석 값의 평균값에 2 배의 편차 값을 더한 값이며, 조치상한선과 조치하한선은 분석 값의 평균 값에 3 배의 편차 값을 더한 값을 이용하였다(Park 등, 2018). 또한 참값을 아는 인증표준물질 SRM 2387(Peanut butter)을 이용하여 회수율 및 정확성을 검증하여 분석 품 질을 확인하였다.

\section{검출한계(LOD)와 정량한계(LOQ)}

본 실험에서 얻어진 ICP chromatogram으로부터 각 분석 물질 주변 peak의 신호/잡음(signal/noise, $\mathrm{S} / \mathrm{N})$ 의 비율이 3.3 에 해당하는 각각의 농도를 검출한계(limit of detection, $\mathrm{LOD}$ )로 하였으며, $\mathrm{S} / \mathrm{N}$ 비 10 에 해당하는 각각의 농도를

Table 1. ICP-OES and ICP-MS conditions for mineral measurement

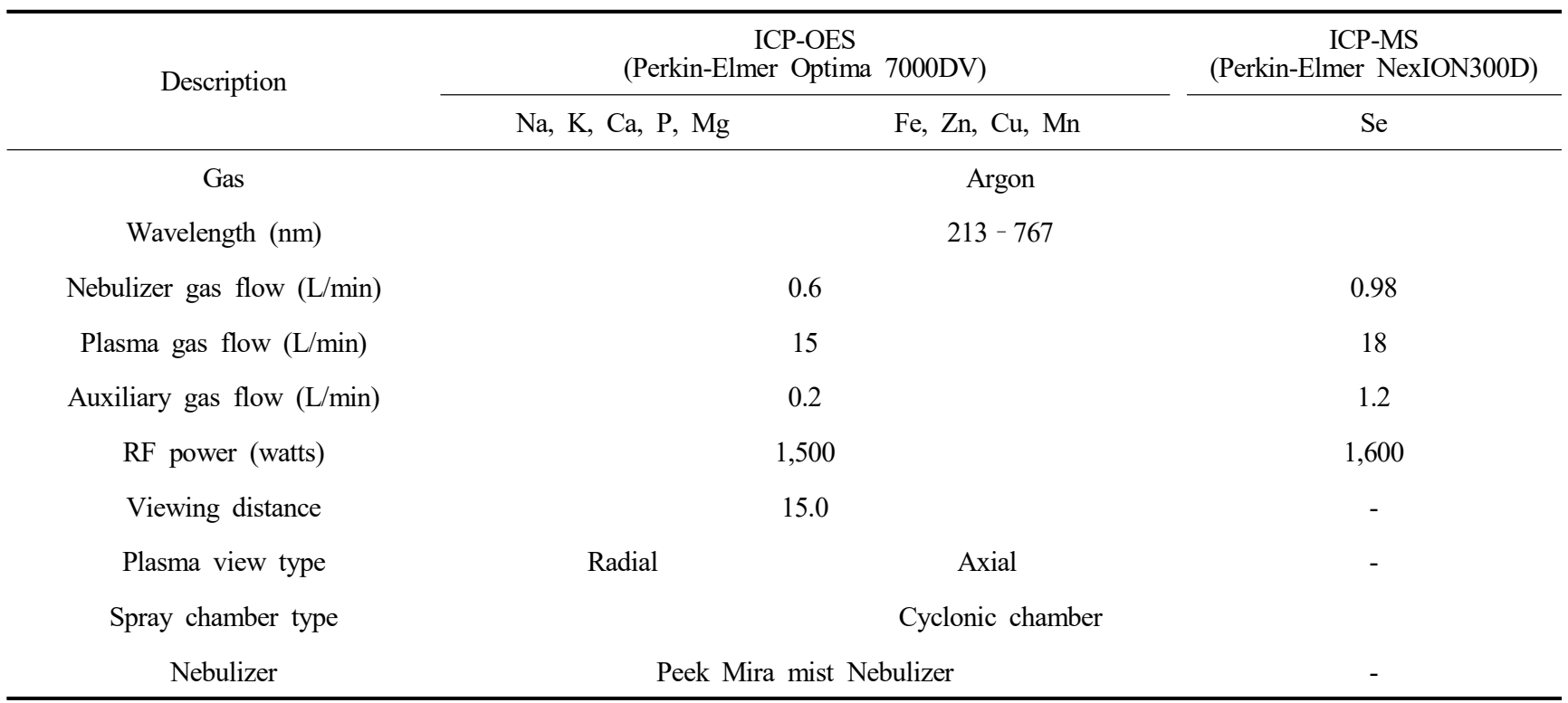


정량한계(limit of quantitation, LOQ)로 계산하였다.

\section{통계처리}

각 무기질 및 회분의 분석 정량 값은 SAS 9.2(Statistical Analysis System, SAS Institute Inc., Cary, NC, USA)를 이용 하여 시료간의 차이 유무를 분산분석(ANOVA)을 시행한 후, Duncan's multiple range test $(\mathrm{p}<0.05)$ 를 실시하여 각 시료 간의 유의성을 검증하였다.

\section{결과 및 고찰}

\section{무기질 및 회분 분석을 위한 내부 분석품질관리}

무기질 및 회분 분석값의 품질관리를 위해 분석품질관 리도표(QC 차트)를 작성하여 분석 결과에 대한 신뢰도를 확인하였다(Fig. 1). 시판조제 분유를 10 회 이상 반복하여
10 종의 무기질 및 회분을 분석하여, 그중 나트륨은 178.27 $\mathrm{mg} / 100 \mathrm{~g}$, 칼슘 $834.13 \mathrm{mg} / 100 \mathrm{~g}$, 인 $530.65 \mathrm{mg} / 100 \mathrm{~g}$, 칼륨 $931.67 \mathrm{mg} / 100 \mathrm{~g}$, 마그네슘 $69.67 \mathrm{mg} / 100 \mathrm{~g}$ 의 표준 값을 얻었고, 또한 철 $8,670.15 \mu \mathrm{g} / 100 \mathrm{~g}$, 구리 $273.84 \mu \mathrm{g} / 100$ $\mathrm{g}$, 아연 4,184.65 $\mu \mathrm{g} / 100 \mathrm{~g}$, 망간 $68.63 \mu \mathrm{g} / 100 \mathrm{~g}$, 셀레늄 $26.00 \mu \mathrm{g} / 100 \mathrm{~g}$ 그리고 회분에서 $4.16 \mathrm{~g} / 100 \mathrm{~g}$ 의 표준 값을 얻었다. 이들 표준 값을 활용하여 내부분석 품질을 검토한 결과, 10 종의 무기질 및 회분 성분의 분석 값이 모두 관리 상하한선에 포함되어 시료를 분석하는 동안 분석에 대한 신뢰도를 검증하였다.

그리고 10 종 무기질에 대한 LOD 및 LOQ는 Table 2 와 같았으며, 인증표준물질을 이용하여 무기질의 회수율 및 정확성을 검증한 결과는 미국국립표준연구원(National Institute of Standards and Technology, NIST)에서 제시하는 인증 값이 없는 $\mathrm{Se}$ 을 제외한 9종의 무기질을, 이들 인증
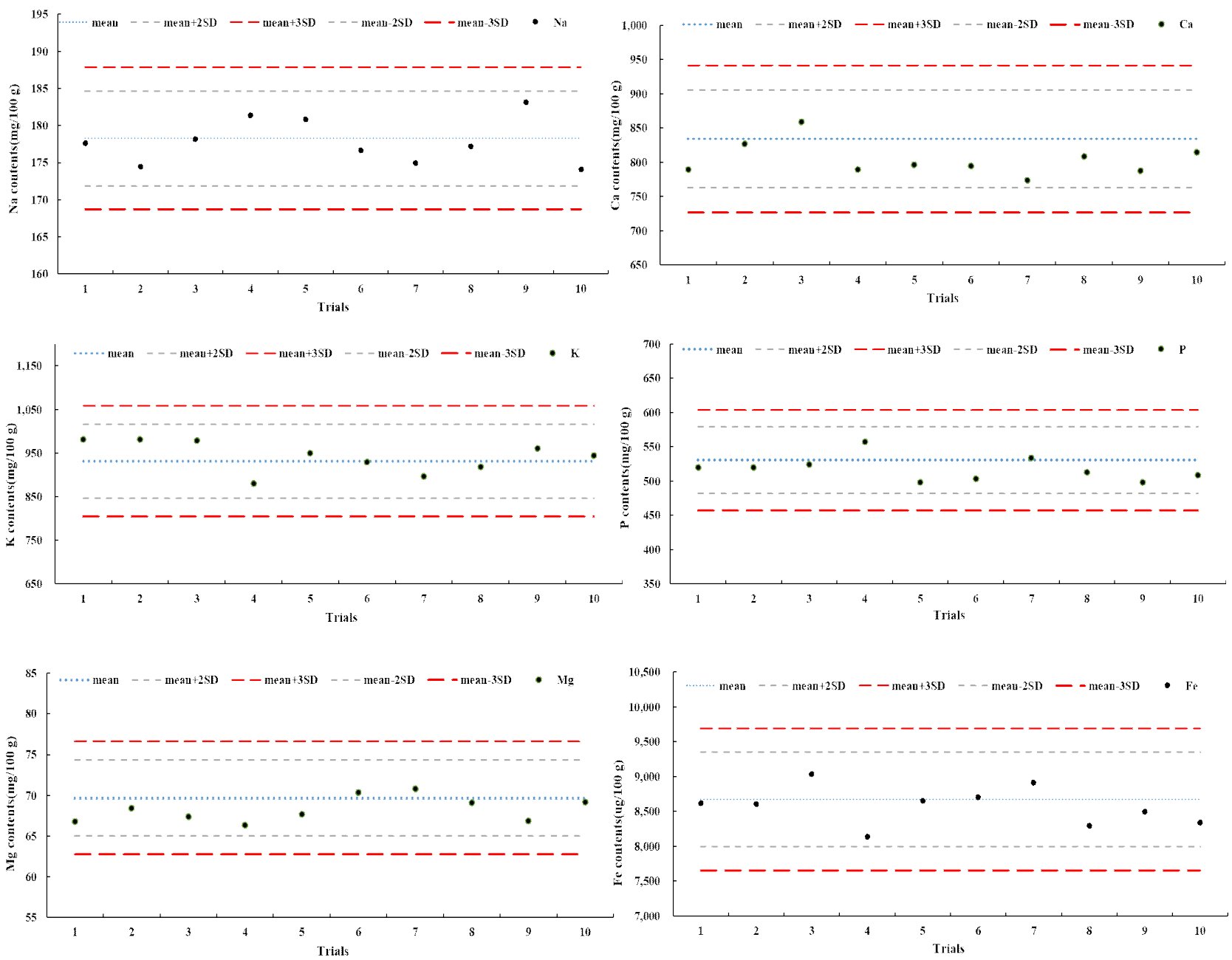

Fig. 1. Quality control charts of $\mathbf{1 0}$ minerals and ash analysis using an infant formular.

mean+2D, Upper control line; mean-2D, Lower control line; mean+3D, Upper action line; and mean-3D, Lower action line. 

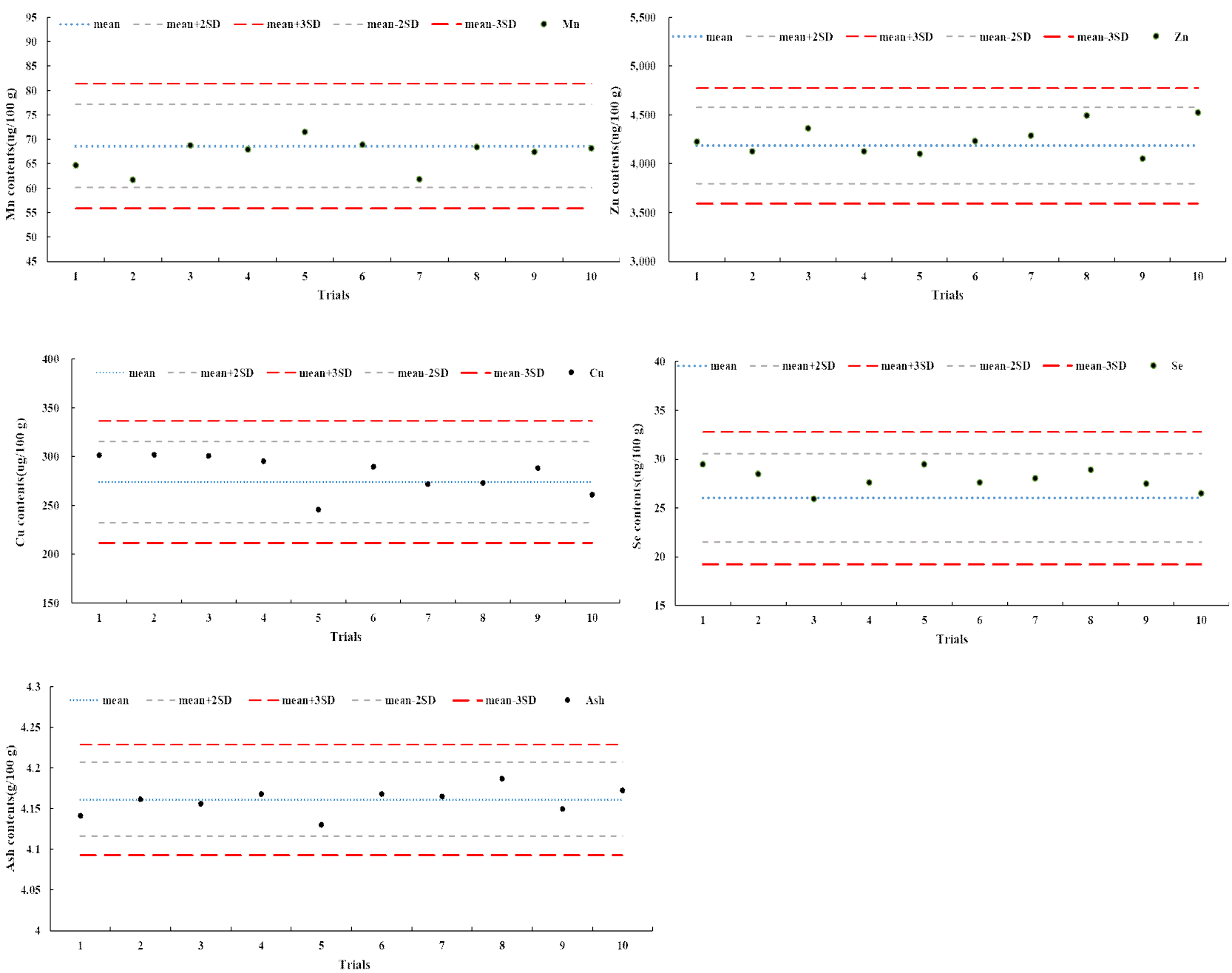

Fig. 1. Quality control charts of $\mathbf{1 0}$ minerals and ash analysis using an infant formular (continued). mean+2D, Upper control line; mean-2D, Lower control line; mean+3D, Upper action line; and mean-3D, Lower action line.

Table 2. Comparison of the LOD and LOQ value of minerals

\begin{tabular}{|c|c|c|c|c|c|}
\hline \multirow{2}{*}{ Component } & LOD & LOQ & \multirow{2}{*}{ Component } & LOD & LOQ \\
\hline & & & & \multicolumn{2}{|c|}{$\mu \mathrm{g} / \mathrm{kg}$} \\
\hline $\mathrm{Na}$ & 0.002 & 0.005 & $\mathrm{Fe}$ & 0.272 & 0.907 \\
\hline $\mathrm{Ca}$ & 0.002 & 0.007 & $\mathrm{Zn}$ & 0.165 & 0.550 \\
\hline K & 0.010 & 0.034 & $\mathrm{Cu}$ & 0.205 & 0.684 \\
\hline $\mathrm{P}$ & 0.006 & 0.018 & $\mathrm{Mn}$ & 0.175 & 0.582 \\
\hline $\mathrm{Mg}$ & 0.004 & 0.012 & $\mathrm{Se}$ & 0.386 & 1.287 \\
\hline
\end{tabular}

값과 비교하였을 때 $99.8-105.5 \%$ 의 회수율과 $\mathrm{RSD}$ 가 0.1 - $3.7 \%$ 로 나타내어 분석에 대한 높은 정확성을 확인하였 다(Table 3).
시판 소스류의 회분 함량

26 종의 소스류에 함유된 회분 함량을 분석한 결과는 Table 4와 같이, 소스류의 회분 함량은 $1.08-12.79 \mathrm{~g} / 100$ 
Table 3. Recovery and RSD values of mineral contents for SRM 2387 (Standard reference material 2387 peanut butter)

\begin{tabular}{|c|c|c|c|c|c|}
\hline Component & Unit & Reference value & Analysis value & Recovery (\%) & $\operatorname{RSD}^{1)}(\%)$ \\
\hline $\mathrm{Na}$ & \multirow{5}{*}{$\mathrm{mg} / 100 \mathrm{~g}$} & $4,890 \pm 140^{2)}$ & $4,914 \pm 54$ & $100.5 \pm 1.8$ & 1.8 \\
\hline $\mathrm{Ca}$ & & $411 \pm 18$ & $423 \pm 19$ & $102.9 \pm 0.1$ & 0.1 \\
\hline $\mathrm{K}$ & & $6,070 \pm 200$ & $6,052 \pm 23$ & $99.8 \pm 2.9$ & 2.9 \\
\hline $\mathrm{P}$ & & $3,378 \pm 92$ & $3,417 \pm 19$ & $101.1 \pm 2.8$ & 2.8 \\
\hline $\mathrm{Mg}$ & & $1,680 \pm 70$ & $1,771 \pm 29$ & $105.5 \pm 2.7$ & 2.5 \\
\hline $\mathrm{Fe}$ & \multirow{4}{*}{$\mu \mathrm{g} / 100 \mathrm{~g}$} & $16.4 \pm 0.8$ & $16.6 \pm 0.2$ & $101.3 \pm 3.7$ & 3.7 \\
\hline $\mathrm{Zn}$ & & $26.3 \pm 1.1$ & $26.4 \pm 0.6$ & $100.4 \pm 1.9$ & 1.9 \\
\hline $\mathrm{Cu}$ & & $4.93 \pm 0.15$ & $4.93 \pm 0.02$ & $100.1 \pm 2.6$ & 2.6 \\
\hline $\mathrm{Mn}$ & & $16.0 \pm 0.6$ & $16.1 \pm 0.3$ & $100.7 \pm 1.9$ & 1.9 \\
\hline
\end{tabular}

${ }^{1)} \mathrm{RSD}$, Relative standard deviation.

${ }^{2)}$ The values represent mean \pm SD of 3 replications.

$\mathrm{g}$ 으로 시료에 따라 차이가 크게 나타났다. 소스류 중에서 곤드레나물밥 양념장, 팔도만능양념장, 콩닥콩닥애 간장 소스(무침, 조림용)순으로 높은 회분 함량을 보였고, 특히 곤드레나물밥 양념장은 $12.79 \pm 0.02 \mathrm{~g} / 100 \mathrm{~g}$ 으로 유의적으 로 가장 높은 회분 값을 보였다. 반면에 청정원 카레여왕 망고\&바나나 조리예에 맞춰 조리한 카레소스에서 $1.08 \pm 0.01 \mathrm{~g} / 100 \mathrm{~g}$ 의 유의적으로 가장 낮은 회분 함량을 나타내었다. 이는 소스류 중 곤드레나물밥 양념장에서 나 트륨, 칼륨, 인, 마그네슘의 함량과 함께 아연, 셀레늄, 망 간, 철의 함량이 다른 소스류에 비해 유의적으로 가장 높았 으므로 회분 함량에서도 유의적으로 가장 높음을 알 수 있었다. 그리고 26 종의 소스류 중 양념으로 표기된 제품에 서 $4.16 \pm 0.00 \mathrm{~g} / 100 \mathrm{~g}$ 이상의 회분 함량을 보여 시판 소스로 표기된 제품보다 더 높은 회분 함량을 나타냄을 확인하였 다. 양념장에서 높은 회분 함량을 나타낸 것은 된장 및 간장의 회분 함량이 각각 $12.53 \pm 0.12 \mathrm{~g} / 100 \mathrm{~g}$ 및 $19.19 \pm 0.34$ $\mathrm{g} / 100 \mathrm{~g}$ 이라는 Lee와 Mun(2012)의 보고처럼, 양념장 내에 이들 성분의 함유로 인해 회분 함량도 증가한 것으로 사료 되었다.

\section{시판 소스류의 무기질 함량}

국내에서 유통되어 소비되는 26종의 소스류에 함유된 10 종의 무기질인 나트륨, 칼슘, 인, 칼륨, 마그네슘, 철, 구리, 아연, 망간 및 셀레늄의 함량을 분석하였다.

Table 5에서 나타낸 것처럼 26종 소스류의 나트륨 함량 은 $272.68-4,336.56 \mathrm{mg} / 100 \mathrm{~g}$ 으로 함량 차이가 매우 컸으 며, 그중 $100 \mathrm{~g}$ 당 소스류 중 곤드레나물밥 양념장에서 유의 적으로 가장 높은 $4,336.56 \pm 67.34 \mathrm{mg}$ 함량을 보였고, 팔도 만능양념장 $3,391.40 \pm 38.40 \mathrm{mg}$ 및 주부초밥왕 새콤달콤
유부초밥 식초양념 $3,125.37 \pm 181.38 \mathrm{mg}$ 으로 높은 나트륨 함량을 보였다. 반면 청정원 카레여왕 망고\&바나나 조리 예에 맞춰 조리한 카레소스에서 유의적으로 가장 낮은 $272.68 \pm 8.86 \mathrm{mg} / 100 \mathrm{~g}$ 함량을 나타내었다. 토마토스파게 티소스 $551.42 \pm 9.91 \mathrm{mg} / 100 \mathrm{~g}$, 프레스코 토마토스파게티소 스 $589.01 \pm 3.15 \mathrm{mg} / 100 \mathrm{~g}$, 풀무원 생가득 4가지 치즈크림 스파게티 크림소스 $588.35 \pm 18.05 \mathrm{mg} / 100 \mathrm{~g}$, 볼로냐스파게 티 토마토스파게티소스 $673.59 \pm 8.86 \mathrm{mg} / 100 \mathrm{~g}$ 에서도 비교 적 낮은 나트륨 함량을 보였으며, 그 외 소스류에서도 100 $\mathrm{g}$ 당 1,000-2,600 mg 정도의 나트륨 함량을 나타내었다.

시판 소스류 26종 중 양념이라는 제품명으로 시판되는 제품에서 높은 나트륨 함량을 나타냄을 알 수 있었는데, 이는 고추장, 된장, 간장 등이 첨가되어(Lee와 Mun, 2012; Choi 등, 2013) 다른 소스류보다는 높은 나트륨 함량을 나타낸 것으로 사료되었다. 또한, 소스류의 나트륨 함량이 $222-4,881 \mathrm{mg}$ 이었다는 $\operatorname{Lee}(2008)$ 의 보고와 유사한 경향 이었으며, 나트륨의 1 일 충분 섭취량은 $1,500 \mathrm{mg}$ 으로, 일상 적인 식생활에 의해서 보편적으로 많이 섭취되고 있는데, 분석한 시판 소스류 18 종에서 $100 \mathrm{~g}$ 당 $1,500 \mathrm{mg}$ 이상의 높은 나트륨 함량을 나타내었다. 특히 콩닥콩닥애 간장소 스(무침, 조림용), 청정원 돼지갈비양념, 청정원 소불고기 양념장, 팔도만능비빔장, 곤드레나물밥 양념장, 주부초밥 왕 새콤달콤 유부초밥 식초양념의 경우 1 일 권장섭취량의 1.5 - 2 배 이상 나트륨이 함유되어 이들 제품에 대한 섭취 시 주의가 필요한 것으로 판단되었다.

소스류의 칼슘 함량은 풀무원 생가득 4가지 치즈크림 스파게티 크림소스에서 유의적으로 가장 높은 $108.36 \pm$ $3.08 \mathrm{mg} / 100 \mathrm{~g}$ 의 함량을 나타내었고, 나머지 소스류에서는 $5.93-43.64 \mathrm{mg} / 100 \mathrm{~g}$ 의 칼슘 함량을 나타내었다. 이는 풀 
Table 4. Ash contents in 26 kinds of domestic commercial sauces

\begin{tabular}{|c|c|}
\hline Sample & Content $(\mathrm{g} / 100 \mathrm{~g})$ \\
\hline Fresco tomato spaghetii sauce & $2.21 \pm 0.01^{\mathrm{rs} 1)}$ \\
\hline Bolognaspaghetii tomatospaghetii sauce & $2.28 \pm 0.02^{\mathrm{r}}$ \\
\hline Pulmuone saeng-gadeug 4gaji cheesecream spaghetii cream sauce & $2.00 \pm 0.03^{\mathrm{t}}$ \\
\hline Chungjungwon kaleyeowang Mango\&Banana joliyee majchwo jolihan curry sauce & $1.08 \pm 0.01^{\mathrm{u}}$ \\
\hline Hamheungbibimnaengmyeon cold noodle sauce & $3.10 \pm 0.02^{\mathrm{p}}$ \\
\hline Kongdagkongdag-ae soy sauce & $8.08 \pm 0.01^{\mathrm{c}}$ \\
\hline Baekseol teriyaki sauce & $5.72 \pm 0.01^{\mathrm{h}}$ \\
\hline Baekseol don kacheu sauce & $6.40 \pm 0.02^{\mathrm{f}}$ \\
\hline Kangdoenjang deopbab sauce & $3.18 \pm 0.02^{\mathrm{p}}$ \\
\hline Tomato spaghetii sauce & $2.14 \pm 0.03^{\mathrm{s}}$ \\
\hline Samgyeobsal yangpajeol-im sauce & $5.01 \pm 0.03^{1}$ \\
\hline Tai sweetchili sauce & $2.98 \pm 0.01^{\mathrm{q}}$ \\
\hline Cheongjeongwon pork ribs seasoning & $5.57 \pm 0.06^{\mathrm{i}}$ \\
\hline Cheongjeongwon gochujang pork bulgogi sauce & $6.02 \pm 0.03^{\mathrm{g}}$ \\
\hline Cheongjeongwon cow bulgogi sauce & $6.56 \pm 0.04^{\mathrm{e}}$ \\
\hline Baekseol Pork ribs seasoning & $5.14 \pm 0.03^{\mathrm{k}}$ \\
\hline Baekseol saliwon Bulgogi sauce & $4.65 \pm 0.03^{\mathrm{m}}$ \\
\hline Andongijimdalg sauce & $5.96 \pm 0.02^{\mathrm{g}}$ \\
\hline Maekomkalkal shindangdong gugmul tteokbokki sauce & $5.60 \pm 0.03^{\mathrm{i}}$ \\
\hline Maekomdalcom haggyoap tteokbokki sauce & $4.54 \pm 0.01^{\mathrm{n}}$ \\
\hline Baekseol tteokbokki sauce & $4.16 \pm 0.00^{\circ}$ \\
\hline Paldo manneungbibimjang & $8.23 \pm 0.23^{b}$ \\
\hline Gondeulenamulbab yangnyeomjang & $12.79 \pm 0.02^{\mathrm{a}}$ \\
\hline Jubuchobab-wang saekomdalkom yubuchobab vinegar sauce & $7.64 \pm 0.04^{\mathrm{d}}$ \\
\hline Goma recipe jjamppongsundubujjigae sauce & $5.24 \pm 0.02^{\mathrm{k}}$ \\
\hline Goma recipe sagol-ypgsubudaejjigae sauce & $5.10 \pm 0.03^{\mathrm{j}}$ \\
\hline F-value & $5,877.05^{* * *}$ \\
\hline
\end{tabular}

${ }^{1)}$ All values represent the mean $\pm \mathrm{SD}$ of triplicate determinations.

${ }^{a-s}$ Means with different superscripts are significantly different by a Duncan's range test at $\mathrm{p}<0.05$.

${ }^{* * *}$ Significant at $\mathrm{p}<0.001$.

무원 생가득 4가지 치즈크림 스파게티 크림소스의 경우에 는 치즈가 함유되어 다른 소스류에 비해 높은 칼슘 함량을 나타내었고, 그 외 소스류에서의 칼슘 함량은 크게 높지 않음을 알 수 있었다. 또한, 토마토스파게티소스의 칼슘 함량은 $17.70-34.50 \mathrm{mg} / 100 \mathrm{~g}$ 으로 시판 스파게티 소스내 칼슘 함량이 $32.0 \pm 0.4 \mathrm{mg} / 100 \mathrm{~g}$ 이라는 보고(Kang 등, 2007)
와 유사한 경향을 보였다. 칼슘은 인체의 구성과 성장에 필요한 주요 영양소이며, 골 손실을 최소화하고 골다공증 예방에 효과가 큰 것으로 알려져 있으나(Hwang 등, 2017), 최근 인스턴트 식품 및 기타 가공식품의 다량 섭취로 칼숨 의 부족 현상이 뚜렷하여 칼슘의 섭취를 권장하고 있다. 한국인 19-64세 성인 남녀의 칼슘 권장섭취량은 남녀 
Table 5. Macromineral contents in domestic commercial sauces

\begin{tabular}{|c|c|c|c|c|c|}
\hline \multirow{2}{*}{ Sample } & \multicolumn{5}{|c|}{ Content (mg/100 g) } \\
\hline & $\mathrm{Na}$ & $\mathrm{Ca}$ & $\mathrm{K}$ & $\mathrm{P}$ & $\mathrm{Mg}$ \\
\hline Fresco tomato spaghetiisauce & $589.01 \pm 3.15^{\mathrm{ml})}$ & $34.50 \pm 0.48^{\mathrm{c}}$ & $310.80 \pm 2.63^{\mathrm{c}}$ & $27.51 \pm 0.41^{\mathrm{n}}$ & $17.49 \pm 0.42^{\mathrm{jk}}$ \\
\hline Bolognaspaghetii tomatospaghetiisauce & $673.59 \pm 18.90^{\mathrm{m}}$ & $17.70 \pm 1.69^{\mathrm{ef}}$ & $448.76 \pm 10.31^{\mathrm{a}}$ & $68.94 \pm 3.79^{\mathrm{e}}$ & $20.43 \pm 0.49^{\mathrm{i}}$ \\
\hline $\begin{array}{l}\text { Pulmuone saeng-gadeug 4gaji cheese } \\
\text { creamspaghetii cream sauce }\end{array}$ & $588.35 \pm 18.05^{\mathrm{m}}$ & $108.36 \pm 3.08^{\mathrm{a}}$ & $140.13 \pm 36.36^{1}$ & $99.66 \pm 2.93^{\mathrm{b}}$ & $11.70 \pm 0.30^{\mathrm{p}}$ \\
\hline $\begin{array}{l}\text { Chungjungwon kaleyeowang Mango\&Banana joliyee } \\
\text { majchwo jolihan currysauce }\end{array}$ & $272.68 \pm 8.86^{\mathrm{n}}$ & $13.93 \pm 2.42^{\mathrm{g}}$ & $180.38 \pm 4.38^{\mathrm{hi}}$ & $53.89 \pm 0.64^{\mathrm{h}}$ & $13.69 \pm 0.30^{\circ}$ \\
\hline Hamheungbibimnaengmyeon cold noodle sauce & $991.94 \pm 16.81^{1}$ & $16.38 \pm 0.84^{\mathrm{fg}}$ & $243.22 \pm 4.85^{\mathrm{f}}$ & $89.95 \pm 0.77^{\mathrm{c}}$ & $27.34 \pm 0.49^{d}$ \\
\hline Kongdagkongdag-ae soy sauce & $2,572.70 \pm 77.73^{\mathrm{d}}$ & $23.72 \pm 0.18^{\mathrm{d}}$ & $242.17 \pm 8.85^{\mathrm{f}}$ & $82.19 \pm 1.72^{\mathrm{d}}$ & $74.45 \pm 0.32^{\mathrm{a}}$ \\
\hline Baekseol teriyaki sauce & $1,927.05 \pm 14.79^{\text {gh }}$ & $19.09 \pm 1.04^{\mathrm{e}}$ & $150.38 \pm 0.56^{\mathrm{kl}}$ & $46.57 \pm 0.46^{\mathrm{ijk}}$ & $17.54 \pm 0.01^{\mathrm{jk}}$ \\
\hline Baekseol don kacheu sauce & $2,086.56 \pm 12.87^{\mathrm{ef}}$ & $34.99 \pm 0.28^{\mathrm{c}}$ & $269.60 \pm 2.98^{\mathrm{e}}$ & $35.61 \pm 0.38^{\mathrm{m}}$ & $16.83 \pm 0.15^{\mathrm{lm}}$ \\
\hline Kangdoenjang deopbab sauce & $1,110.48 \pm 102.80^{\mathrm{k}}$ & $12.15 \pm 2.63^{\mathrm{d}}$ & $184.19 \pm 18.68^{\mathrm{h}}$ & $115.95 \pm 12.61^{\mathrm{a}}$ & $20.26 \pm 2.02^{\mathrm{i}}$ \\
\hline Tomato spaghetii sauce & $551.42 \pm 9.91^{\mathrm{m}}$ & $23.56 \pm 1.39^{\mathrm{d}}$ & $367.55 \pm 1.92^{\mathrm{b}}$ & $35.97 \pm 0.23^{\mathrm{m}}$ & $16.74 \pm 0.09^{1 \mathrm{~m}}$ \\
\hline Samgyeobsal yangpajeol-im sauce & $2,157.98 \pm 24.68^{\mathrm{e}}$ & $7.65 \pm 0.24^{\mathrm{ij}}$ & $111.16 \pm 2.94^{\mathrm{m}}$ & $29.96 \pm 0.26^{\mathrm{n}}$ & $13.03 \pm 0.11^{\circ}$ \\
\hline Tai sweetchili sauce & $1,114.83 \pm 8.94^{\mathrm{k}}$ & $6.51 \pm 0.07^{\mathrm{j}}$ & $85.80 \pm 2.64^{\mathrm{n}}$ & $10.66 \pm 0.32^{\circ}$ & $4.65 \pm 0.10^{\mathrm{r}}$ \\
\hline Cheongjeongwon pork ribs seasoning & $2,599.96 \pm 233.79^{d}$ & $16.00 \pm 1.04^{\mathrm{fg}}$ & $163.19 \pm 16.27^{\mathrm{jk}}$ & $44.74 \pm 3.83^{\mathrm{jkl}}$ & $22.12 \pm 2.20^{\mathrm{h}}$ \\
\hline Cheongjeongwon gochujang pork bulgogi sauce & $2,190.61 \pm 20.52^{\mathrm{e}}$ & $24.13 \pm 1.64^{\mathrm{d}}$ & $289.89 \pm 1.73^{\mathrm{d}}$ & $64.64 \pm 0.78^{\mathrm{ef}}$ & $27.01 \pm 0.83^{\mathrm{de}}$ \\
\hline Cheongjeongwon cow bulgogi sauce & $2,550.30 \pm 63.17^{\mathrm{d}}$ & $17.64 \pm 0.94^{\mathrm{ef}}$ & $177.72 \pm 1.18^{\mathrm{hij}}$ & $49.85 \pm 0.45^{\text {hij }}$ & $23.54 \pm 0.48^{\mathrm{g}}$ \\
\hline Baekseol Pork ribs seasoning & $1,824.56 \pm 13.08^{\mathrm{h}}$ & $9.83 \pm 0.08^{\mathrm{hi}}$ & $153.64 \pm 0.83^{\mathrm{kl}}$ & $59.38 \pm 0.68^{\mathrm{g}}$ & $15.88 \pm 0.08^{\mathrm{n}}$ \\
\hline Baekseol saliwon Bulgogi sauce & $1,621.47 \pm 44.86^{\mathrm{i}}$ & $20.15 \pm 1.87^{\mathrm{e}}$ & $192.68 \pm 1.32^{\mathrm{h}}$ & $45.55 \pm 0.38^{\mathrm{jkl}}$ & $31.20 \pm 0.25^{\mathrm{c}}$ \\
\hline Andongijimdalg sauce & $2,018.39 \pm 5.70^{\mathrm{fg}}$ & $10.42 \pm 0.32^{\mathrm{h}}$ & $143.32 \pm 0.40^{1}$ & $49.08 \pm 0.41^{\mathrm{hijk}}$ & $18.88 \pm 0.02^{\mathrm{j}}$ \\
\hline $\begin{array}{l}\text { Maekomkalkal shindangdong gugmul tteokbokki } \\
\text { sauce }\end{array}$ & $1,999.12 \pm 6.78^{\mathrm{fg}}$ & $15.21 \pm 0.77^{\mathrm{fg}}$ & $216.14 \pm 2.69^{\mathrm{g}}$ & $63.38 \pm 2.79^{\mathrm{fg}}$ & $25.78 \pm 1.18^{\mathrm{ef}}$ \\
\hline Maekomdalcom haggyoap tteokbokki sauce & $1,606.68 \pm 22.67^{\mathrm{i}}$ & $23.44 \pm 0.73^{\mathrm{d}}$ & $167.02 \pm 5.41^{\mathrm{ijk}}$ & $51.77 \pm 1.20^{\mathrm{hi}}$ & $18.00 \pm 0.64^{\mathrm{jk}}$ \\
\hline Baekseol tteokbokki sauce & $1,331.86 \pm 17.94^{\mathrm{j}}$ & $14.34 \pm 0.72^{\mathrm{g}}$ & $290.90 \pm 2.66^{\mathrm{d}}$ & $88.56 \pm 1.57^{\mathrm{c}}$ & $24.95 \pm 0.36^{\mathrm{f}}$ \\
\hline Paldo manneungbibimjang & $3,391.40 \pm 38.40^{b}$ & $22.81 \pm 2.62^{\mathrm{d}}$ & $303.12 \pm 1.36^{\mathrm{cd}}$ & $90.71 \pm 2.98^{\mathrm{c}}$ & $27.72 \pm 0.76^{\mathrm{d}}$ \\
\hline Gondeulenamulbab yangnyeomjang & $4,336.56 \pm 67.34^{\mathrm{a}}$ & $43.64 \pm 3.42^{b}$ & $370.94 \pm 9.44^{\mathrm{b}}$ & $100.63 \pm 0.77^{b}$ & $62.06 \pm 13.37^{\mathrm{b}}$ \\
\hline $\begin{array}{l}\text { Jubuchobab-wang saekomdalkom yubuchobab } \\
\text { vinegar sauce }\end{array}$ & $3,125.37 \pm 181.38^{\mathrm{c}}$ & $5.93 \pm 0.38^{\mathrm{j}}$ & $51.74 \pm 8.13^{\circ}$ & $7.81 \pm 0.41^{\circ}$ & $2.69 \pm 0.17^{\mathrm{s}}$ \\
\hline Goma recipe jjamppongsundubujjigae sauce & $1,993.19 \pm 42.70^{\mathrm{fg}}$ & $15.00 \pm 0.54^{\mathrm{fg}}$ & $97.15 \pm 1.79^{\mathrm{mn}}$ & $40.83 \pm 0.89^{1}$ & $10.42 \pm 0.22^{\mathrm{q}}$ \\
\hline 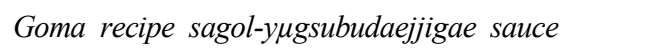 & $1,864.40 \pm 70.46^{\mathrm{h}}$ & $15.00 \pm 0.66^{\mathrm{fg}}$ & $141.43 \pm 0.61^{1}$ & $44.34 \pm 0.82^{\mathrm{kl}}$ & $18.04 \pm 0.43^{\mathrm{jk}}$ \\
\hline F-value & $566.62^{* * *}$ & $513.42^{* * *}$ & $305.45^{* * *}$ & $267.21^{* * *}$ & $1167.44^{* * *}$ \\
\hline
\end{tabular}

${ }^{1)}$ All values represent the mean $\pm \mathrm{SD}$ of triplicate determinations.

${ }^{\mathrm{a}-\mathrm{r}}$ Means with different superscripts are significantly different by a Duncan's range test at $\mathrm{p}<0.05$. ${ }^{* * *}$ Significant at $\mathrm{p}<0.001$.

각각 $800 \mathrm{mg} /$ day, $700 \mathrm{mg} / \mathrm{day}$ (The Korean Nutrition Society, 2015)로, 소스류 중 가장 칼슘 함량이 높은 풀무원 생가득 4가지 치즈크림 스파게티 크림소스 $100 \mathrm{~g}$ 을 섭취하면 $15 \%$
정도의 칼슘 공급이 가능하였으나, 그 외 소스류 섭취로는 $0.7-5.8 \%$ 로 아주 낮은 칼슘 공급이 가능함을 알 수 있었 다. 
칼륨 함량은 26 종 소스류의 무기질 함량 중 나트륨 다음 으로 많이 함유되어 있었으며, 소스류의 칼륨 함량은 51.74$448.76 \mathrm{mg} / 100 \mathrm{~g}$ 으로 비교적 시료 간에 차이를 보였다. 그중 $100 \mathrm{~g}$ 당 볼로냐스파게티 토마토스파게티소스에서 유의적으로 가장 높은 $448.76 \pm 10.31 \mathrm{mg}$ 의 칼륨이 함유되 었으며, 곤드레나물밥 양념장 $370.94 \pm 9.44 \mathrm{mg}$ 및 토마토스 파게티소스 $367.55 \pm 1.92 \mathrm{mg}$ 으로 높은 칼륨 함량을 나타내 었다. 반면 주부초밥왕 새콤달콤 유부초밥 식초양념에서 $51.74 \pm 8.13 \mathrm{mg} / 100 \mathrm{~g}$ 으로 유의적으로 가장 낮은 칼륨 함량 을 나타내었다. 또한, 토마토스파게티 소스류의 칼륨 함량 은 $310.80-448.76 \mathrm{mg} / 100 \mathrm{~g}$ 으로 시판 스파게티소스 내 칼륨 함량이 $467.9 \mathrm{mg} / 100 \mathrm{~g}$ 이라는 보고(Kang 등, 2007)와 유사한 값을 보임을 알 수 있었다. 특히 토마토에는 칼륨 함량이 높다고 알려져(Chun과 Han, 2000) 이들 토마토스 파게티 소스에서 높은 칼륨 함량을 보이는 것으로 사료되 었다.

또한, 나트륨/칼륨 $(\mathrm{Na} / \mathrm{K})$ 비율을 1 에 가깝게 낮추면 고 혈압의 예방과 개선에 효과적이라는 보고(NIAS, 2018)와 비교해서, 토마토스파게티 소스류의 나트륨 및 칼륨 함량 이 각각 $551.42-673.59 \mathrm{mg} / 100 \mathrm{~g}$ 및 $310.80-448.76$ $\mathrm{mg} / 100 \mathrm{~g}$ 으로 일부 시료는 나트륨/칼륨 비율이 1.5 - 1.8로 다른 시판 소스류보다는 낮은 나트륨/칼륨 비율을 보였고, 그 외 대부분의 소스류에서 나트륨/칼륨 비율이 4 배 이상 을 보였다. 특히 주부초밥왕 새콤달콤 유부초밥 식초양념 의 경우 나트륨/칼륨 비율이 60.4로 가장 높은 것으로 나타 났다.

소스류의 인 함량은 $7.81-115.95 \mathrm{mg} / 100 \mathrm{~g}$ 이었으며, 그 중 $100 \mathrm{~g}$ 당 강된장 덮밥소스가 유의적으로 가장 높은 $115.95 \pm 12.61 \pm 12.61 \mathrm{mg}$ 의 인 함량을 보이고, 곤드레나물 밥 양념장은 $100.63 \pm 0.77 \mathrm{mg}$ 의 유의적으로 높은 인 함량을 나타내었다. 반면, 주부초밥왕 새콤달콤 유부초밥 식초양 념은 유의적으로 가장 낮은 $7.81 \pm 0.41 \mathrm{mg} / 100 \mathrm{~g}$ 의 인 함량 을 보이고, 타이 스위트 칠리소스는 유의적으로 낮은 $10.66 \pm 0.32 \mathrm{mg} / 100 \mathrm{~g}$ 의 인 함량을 나타내었다. 토마토스파 게티소스의 인 함량은 $27.51-68.94 \mathrm{mg} / 100 \mathrm{~g}$ 으로 시판 스파게티소스 내 인 함량이 $59.8 \mathrm{mg} / 100 \mathrm{~g}$ 이라는 보고 (Kang, 2007)와 유사한 경향을 보였다. 또한, 일반 자장소 스의 인 함량은 $79 \mathrm{mg} / 100 \mathrm{~g}$ 으로(Kim과 Kim, 2003) 분석한 소스류 중 콩닥콩닥애 간장소스(무침, 조림용), 백설 데리 야끼소스, 백설 떡볶이양념, 팔도 만능비빔장과 유사한 인 함량 값을 나타내었다.

칼슘과 인의 섭취량의 비가 1:1일 때 가장 이용률이 높아 인의 권장량은 칼슘과 동일하게 칼슘 권장섭취량은 남녀 각각 $800 \mathrm{mg} / \mathrm{day}, 700 \mathrm{mg} / \mathrm{day}$ 로 정하고 있다. 그러나 우리 나라 성인의 인 섭취량은 1 일 $600-1,500 \mathrm{mg}$ 으로 칼슘 섭취량에 비해 높아 대략 1:1.5 정도를 보이고 있다. 소스류
중 프레스코 토마토 스파게티소스, 풀무원 생가득 4가지 치즈크림 스파게티 크림소스, 백설 돈카츠소스, 토마토스 파게티소스, 타이 스위트칠리소스, 주부초밥왕 새콤달콤 유부초밥 식초양념은 칼슘과 인의 함량이 $0.8-1.6$ 의 비율 로 함유되어 있었고, 나머지 소스류에서는 칼슘과 인의 함량이 2.2-6.0 비율로 큰 차이를 보임을 알 수 있었다. 인의 다량 섭취는 체내 칼슘 손실을 가져올 수 있고, 철, 구리, 아연의 흡수에도 영향을 미치는 것으로 보고 (Kirchessner, 1978; Haek 등, 1988)되고 있으므로, 인과 칼 슘 함량의 차가 큰 소스류에 대한 섭취 시에는 좀 더 주의가 필요하다고 생각되었다.

소스류의 마그네슘 함량은 $2.69-74.45 \mathrm{mg} / 100 \mathrm{~g}$ 으로 다른 다량 무기질 함량에 비해서 가장 낮게 함유되었다. 그 중 $100 \mathrm{~g}$ 당 콩닥콩닥애 간장소스(무침, 조림용)은 유의 적으로 가장 높은 $74.45 \pm 0.32 \mathrm{mg}$ 의 마그네슘 함량을 보이 고, 곤드레나물밥 양념장은 $62.06 \pm 13.37 \mathrm{mg}$ 의 유의적으로 높은 마그네슘 함량을 나타내었다. 주부초밥왕 새콤달콤

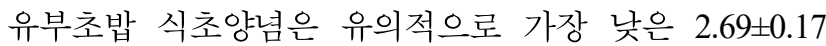
$\mathrm{mg} / 100 \mathrm{~g}$ 의 마그네슘 함량을 보이고, 타이 스위트 칠리소 스도 $4.65 \pm 0.10 \mathrm{mg} / 100 \mathrm{~g}$ 의 유의적으로 낮은 마그네슘 함 량을 나타내었다. 토마토스파게티소스의 마그네슘 함량 은 $16.74-20.43 \mathrm{mg} / 100 \mathrm{~g}$ 으로 시판 스파게티 소스내 마그 네슘 함량이 $31.0 \mathrm{mg} / 100 \mathrm{~g}$ 이라는 Kang 등(2007)의 보고보 다는 적은 값을 보였다. 특히 26종의 소스류 중에서 주부초 밥왕 새콤달콤 유부초밥 식초양념 및 타이 스위트 칠리소 스는 나트륨을 제외한 칼슘, 인, 칼륨, 마그네슘 함량이 유의적으로 가장 낮은 소스였으며, 반면 곤드레나물밥 양 념장은 나트륨, 칼륨, 인, 마그네슘의 함량이 다른 소스류 에 비해 유의적으로 가장 높게 함유되어 있었다.

한편, 소스류의 미량무기질의 함량을 분석한 결과는 Table 6과 같다. 먼저 소스류의 철 함량은 63.36-1,759.02 $\mu \mathrm{g} / 100 \mathrm{~g}$ 으로 소스 종류에 따른 함량 차이가 큰 편이었다. 소스류 중 풀무원 생가득 4 가지 치즈크림 스파게티 크림소 스, 타이 스위트 칠리소스, 주부초밥왕 새콤달콤 유부초밥 식초양념은 $63.36-132.79 \mu \mathrm{g} / 100 \mathrm{~g}$ 의 유의적으로 가장 낮 은 철 함량을 보였고, 반면 토마토스파게티소스는 $1,759.02 \pm 99.36 \mu \mathrm{g} / 100 \mathrm{~g}$ 의 유의적으로 가장 높은 철 함량 을 보였다. 강된장 덮밥소스, 백설 떡볶이양념, 청정원 고 추장돼지불고기양념 및 곤드레나물밥 양념장은 $1,119.13$ $-1,192.13 \mu \mathrm{g} / 100 \mathrm{~g}$ 의 유의적으로 높은 철 함량을 나타내 었다. 일반 자장소스의 철 함량이 $0.8-1.32 \mathrm{mg} / 100 \mathrm{~g}$ 이라 는 Kim과 $\operatorname{Kim}$ (2003)의 보고와 비교해서 분석된 26종 소스 류의 철 함량과 유사하였으며, 특히 시판 스파게티소스 내 철 함량이 $1.0 \mathrm{mg} / 100 \mathrm{~g}$ 이라는 Kang 등(2007)의 보고와 비교해서 분석한 토마토스파게티소스의 철 함량이 582.43 - $1,759.02 \mu \mathrm{g} / 100 \mathrm{~g}$ 으로 약간의 차이를 보였으며 이는 소 
Table 6. Micromineral contents in domestic commercial sauces

\begin{tabular}{|c|c|c|c|c|c|}
\hline \multirow{2}{*}{ Sample } & \multicolumn{5}{|c|}{ Content $(\mu \mathrm{g} / 100 \mathrm{~g})$} \\
\hline & $\mathrm{Fe}$ & $\mathrm{Mn}$ & $\mathrm{Cu}$ & $\mathrm{Zn}$ & $\mathrm{Se}$ \\
\hline Fresco tomato spaghetiisauce & $582.43 \pm 12.05^{\text {fghl })}$ & $103.23 \pm 1.12^{\circ}$ & $111.423 \pm 7.04^{\mathrm{cd}}$ & $94.52 \pm 33.24^{\mathrm{k}}$ & $7.40 \pm 1.29^{\text {efgh }}$ \\
\hline Bolognaspaghetii tomatospaghetiisauce & $596.38 \pm 31.89^{\mathrm{fgh}}$ & $118.55 \pm 2.48^{\mathrm{n}}$ & $102.95 \pm 4.76^{\mathrm{d}}$ & $372.03 \pm 15.59^{\mathrm{bc}}$ & $12.24 \pm 2.85^{\mathrm{de}}$ \\
\hline $\begin{array}{l}\text { Pulmuone saeng-gadeug 4gaji cheese } \\
\text { creamspaghetii cream sauce }\end{array}$ & $63.36 \pm 12.30^{1}$ & $13.26 \pm 1.24^{\mathrm{r}}$ & $18.15 \pm 4.86^{\mathrm{jklm}}$ & $305.71 \pm 13.88^{\mathrm{de}}$ & $9.20 \pm 0.71^{\mathrm{efg}}$ \\
\hline $\begin{array}{l}\text { Chungjungwon kaleyeowang Mango\&Banana } \\
\text { joliyee majchwo jolihan currysauce }\end{array}$ & $457.64 \pm 32.96^{\mathrm{ij}}$ & $183.76 \pm 3.86^{1}$ & $22.34 \pm 0.18^{\mathrm{ijkl}}$ & $242.75 \pm 16.70^{\mathrm{gh}}$ & $4.87 \pm 0.30^{\mathrm{fgh}}$ \\
\hline Hamheungbibimnaengmyeon cold noodle sauce & $981.45 \pm 9.28^{\mathrm{c}}$ & $277.52 \pm 1.47^{\mathrm{h}}$ & $145.74 \pm 11.52^{\mathrm{a}}$ & $212.00 \pm 6.07^{\mathrm{h}}$ & $3.26 \pm 0.34^{\mathrm{h}}$ \\
\hline Kongdagkongdag-ae soy sauce & $1,041.73 \pm 10.74^{\mathrm{c}}$ & $507.04 \pm 5.96^{\mathrm{b}}$ & $3.38 \pm 0.14^{\mathrm{n}}$ & $399.97 \pm 31.70^{\text {cd }}$ & $80.70 \pm 3.59^{b}$ \\
\hline Baekseol teriyaki sauce & $434.99 \pm 9.28^{\mathrm{j}}$ & $236.84 \pm 2.16^{\mathrm{i}}$ & $6.25 \pm 0.63^{\mathrm{mn}}$ & ND & $23.99 \pm 0.59^{\mathrm{c}}$ \\
\hline Baekseol don kacheu sauce & $524.12 \pm 8.68^{\mathrm{hi}}$ & $313.75 \pm 1.61^{\mathrm{ef}}$ & $24.58 \pm 1.69^{\mathrm{hijk}}$ & ND & $1.66 \pm 0.37^{\mathrm{h}}$ \\
\hline Kangdoenjang deopbab sauce & $757.26 \pm 22.64^{\mathrm{e}}$ & $226.04 \pm 5.25^{\mathrm{j}}$ & $118.33 \pm 18.14^{\mathrm{bc}}$ & $448.57 \pm 6.35^{\mathrm{a}}$ & $9.26 \pm 0.83^{\text {efg }}$ \\
\hline Tomato spaghetii sauce & $1,759.02 \pm 99.36^{\mathrm{a}}$ & $137.70 \pm 0.31^{\mathrm{m}}$ & $80.94 \pm 1.17^{\text {ef }}$ & $11.70 \pm 0.96^{\mathrm{m}}$ & $22.36 \pm 1.70^{\mathrm{c}}$ \\
\hline Samgyeobsal yangpajeol-im sauce & $465.07 \pm 7.83^{\mathrm{ij}}$ & $118.87 \pm 1.59^{\mathrm{n}}$ & $33.39 \pm 0.81^{\mathrm{hi}}$ & $59.71 \pm 15.95^{1}$ & $3.16 \pm 0.99^{\mathrm{gh}}$ \\
\hline Tai sweetchili sauce & $118.17 \pm 4.96^{1}$ & $34.77 \pm 0.65^{\mathrm{q}}$ & $12.18 \pm 1.34^{\mathrm{klmn}}$ & $36.83 \pm 2.98^{\mathrm{lm}}$ & $1.72 \pm 0.08^{\mathrm{h}}$ \\
\hline Cheongjeongwon pork ribs seasoning & $595.03 \pm 89.66^{\mathrm{fgh}}$ & $303.42 \pm 26.56^{\mathrm{f}}$ & $25.03 \pm 0.90^{\mathrm{hijk}}$ & $207.72 \pm 11.83^{\mathrm{h}}$ & $1.51 \pm 0.31^{\mathrm{h}}$ \\
\hline Cheongjeongwon gochujang pork bulgogi sauce & $1,162.14 \pm 44.10^{b}$ & $315.37 \pm 0.65^{\mathrm{e}}$ & $114.79 \pm 5.87^{\mathrm{bcd}}$ & $336.47 \pm 59.69^{\text {cd }}$ & $4.17 \pm 1.71^{\mathrm{fgh}}$ \\
\hline Cheongjeongwon cow bulgogi sauce & $608.14 \pm 104.10^{\mathrm{fg}}$ & $362.76 \pm 5.80^{\mathrm{d}}$ & $31.84 \pm 10.26^{\mathrm{hi}}$ & $268.07 \pm 43.54^{\mathrm{fg}}$ & $3.70 \pm 0.63^{\text {fgh }}$ \\
\hline Baekseol pork ribs seasoning & $530.11 \pm 43.06^{\text {ghi }}$ & $239.38 \pm 1.35^{\mathrm{i}}$ & $27.10 \pm 0.65^{\mathrm{hij}}$ & $100.96 \pm 9.19^{k}$ & $4.44 \pm 0.13^{\text {fgh }}$ \\
\hline Baekseol saliwon Bulgogi sauce & $529.24 \pm 13.66^{\text {ghi }}$ & $609.21 \pm 6.97^{\mathrm{a}}$ & $11.10 \pm 0.34^{1 \mathrm{mn}}$ & $125.97 \pm 8.75^{\mathrm{jk}}$ & $15.07 \pm 0.29^{d}$ \\
\hline Andongjjimdalg sauce & $588.23 \pm 2.19^{\text {fgh }}$ & $372.06 \pm 0.65^{\mathrm{d}}$ & $9.82 \pm 0.19^{\operatorname{lmn}}$ & $154.81 \pm 14.11^{\mathrm{i}}$ & $7.24 \pm 1.14^{\text {efgh }}$ \\
\hline $\begin{array}{l}\text { Maekomkalkal shindangdong gugmul tteokbokki } \\
\text { sauce }\end{array}$ & $792.06 \pm 56.90^{\mathrm{de}}$ & $317.59 \pm 7.92^{\mathrm{e}}$ & $71.81 \pm 9.47^{\mathrm{f}}$ & $341.52 \pm 9.03^{\mathrm{cd}}$ & $8.39 \pm 1.38^{\text {efg }}$ \\
\hline Maekomdalcom haggyoap tteokbokki sauce & $632.58 \pm 60.27^{\mathrm{f}}$ & $238.05 \pm 1.31^{\mathrm{i}}$ & $37.57 \pm 5.57^{\mathrm{h}}$ & $282.02 \pm 21.13^{\mathrm{ef}}$ & $3.26 \pm 0.57^{\mathrm{gh}}$ \\
\hline Baekseol tteokbokki sauce & $1,192.13 \pm 6.22^{b}$ & $292.74 \pm 3.15^{\mathrm{g}}$ & $84.31 \pm 13.69^{\mathrm{e}}$ & $345.39 \pm 6.44^{\mathrm{c}}$ & $22.02 \pm 1.09^{\mathrm{c}}$ \\
\hline Paldo manneungbibimjang & $843.12 \pm 39.14^{d}$ & $200.60 \pm 2.24^{\mathrm{k}}$ & $126.54 \pm 13.10^{\mathrm{b}}$ & $400.35 \pm 32.86^{\mathrm{b}}$ & $27.06 \pm 7.56^{\mathrm{c}}$ \\
\hline Gondeulenamulbab yangnyeomjang & $1,119.13 \pm 11.74^{\mathrm{b}}$ & $423.12 \pm 8.81^{\mathrm{c}}$ & $55.32 \pm 5.04^{\mathrm{g}}$ & $451.10 \pm 9.14^{\mathrm{a}}$ & $156.78 \pm 12.55^{\mathrm{a}}$ \\
\hline $\begin{array}{l}\text { Jubuchobab-wang saekomdalkom yubuchobab } \\
\text { vinegar sauce }\end{array}$ & $132.79 \pm 27.35^{1}$ & $7.57 \pm 0.51^{\mathrm{r}}$ & $8.02 \pm 0.85^{\mathrm{mn}}$ & $33.77 \pm 11.98^{\mathrm{lm}}$ & $3.74 \pm 0.79^{\text {fgh }}$ \\
\hline Goma recipe jjamppongsundubujjigae sauce & $309.29 \pm 33.80^{\mathrm{k}}$ & $75.67 \pm 2.95^{\mathrm{p}}$ & $30.30 \pm 9.71^{\text {hij }}$ & $54.10 \pm 12.10^{1}$ & $9.59 \pm 1.15^{\text {ef }}$ \\
\hline Goma recipe sagol-yugsubudaejjigae sauce & $654.16 \pm 43.74^{\mathrm{f}}$ & $114.15 \pm 0.41^{\mathrm{n}}$ & $51.25 \pm 7.50^{\mathrm{g}}$ & $169.35 \pm 7.70^{\mathrm{ij}}$ & $16.35 \pm 0.44^{\mathrm{d}}$ \\
\hline F-value & $226.39^{* * *}$ & $1632.73^{* * *}$ & $110.11^{* * *}$ & $153.32^{* * *}$ & $324.38^{* * *}$ \\
\hline
\end{tabular}

${ }^{1)}$ All values represent the mean $\pm \mathrm{SD}$ of triplicate determinations.

${ }^{\mathrm{a}-\mathrm{r}}$ Means with different superscripts are significantly different by a Duncan's range test at $\mathrm{p}<0.05$.

ND, Not detected. ${ }^{* * *}$ Significant at $\mathrm{p}<0.001$.

스 제조시 첨가되는 원료에 따른 차이로 생각되었다. 또한, 19 - 49세 성인 남녀의 철 1 일 권장섭취량은 남녀 각각
$10 \mathrm{mg}, 14 \mathrm{mg}($ The Korean Nutrition Society, 2015)으로, 26종 소스류 중 철의 최대함유량이 $1,759.02 \pm 99.36 \mu \mathrm{g} / 100 \mathrm{~g}$ 이므 
로 1 일 권장섭취량에 비해서는 철 함유량이 아주 낮은 편임을 알 수 있었다.

소스류의 망간 함량은 7.57-609.21 $\mu \mathrm{g} / 100 \mathrm{~g}$ 으로 소스 종류에 따라 큰 차이를 보였으며, 그 중 주부초밥왕 새콤달 콤 유부초밥 식초양념은 $7.57 \pm 0.51 \mu \mathrm{g} / 100 \mathrm{~g}$, 풀무원 생가 득 4가지 치즈크림 스파게티 크림소스는 $13.26 \pm 1.24$ $\mu \mathrm{g} / 100 \mathrm{~g}$ 으로 유의적으로 가장 낮은 망간 함량을 나타내었 다. 반면, 백설 사리원 불고기양념은 $609.21 \pm 6.97 \mu \mathrm{g} / 100$ $\mathrm{g}$ 으로 유의적으로 가장 높은 망간 함량을 나타내었고, 콩 닥콩닥애 간장소스(무침, 조림용) 및 곤드레나물밥 양념장 은 423.12 - $609.21 \mu \mathrm{g} / 100 \mathrm{~g}$ 의 유의적으로 높은 망간 함량 을 나타내었고, 이들을 제외한 소스에서는 $75.67 \pm 2.95$ $\mu \mathrm{g} / 100 \mathrm{~g}$ 이상의 망간함량을 나타내었다. 망간은 다양한 식품에 함유되어 있으나 식이로 섭취한 망간의 1-3\% 정 도가 흡수되고, 성인의 경우 흡수된 망간 보유율도 1-3\% 로 낮다(Mena, 1981). 또한 망간은 철의 흡수를 억제하며, 칼슘, 아연 등과 같은 무기질의 과잉 섭취 시 망간의 체내 이용률에도 영향을 미칠 수 있다(Sandstrom 등, 1987)고 알려져 있다. 특히 우리나라 식품에 대한 망간 함량에 대한 정확한 자료 제공이 부족한 편이므로, 이들 시판 소스류에 대한 망간 함량에 대한 정보 제공 측면에서 의의가 있다고 판단되었다.

소스류의 구리 함량은 $3.38-145.74 \mu \mathrm{g} / 100 \mathrm{~g}$ 으로 소스 종류에 따라 구리 함량이 큰 차이를 나타내었다. 그 중 함흥비빔냉면 냉면소스는 $145.74 \pm 11.52 \mu \mathrm{g} / 100 \mathrm{~g}$ 의 유의 적으로 가장 높은 구리 함량을 나타내었고, 팔도 만능비빔 장은 $126.54 \pm 13.10 \mu \mathrm{g} / 100 \mathrm{~g}$ 으로 유의적으로 높은 구리 함량을 나타내었다. 반면, 콩닥콩닥애 간장소스(무침, 조 림용), 백설 데리야끼소스, 주부초밥왕 새콤달콤 유부초밥 식초양념, 백설 사리원불고기양념, 타이 스위트 칠리소 스, 안동찜닭양념은 $3.38-9.82 \mu \mathrm{g} / 100 \mathrm{~g}$ 의 유의적으로 가 장 낮은 구리 함량을 나타내었다. Seasoned soy sauce에는 $50 \mu \mathrm{g} / 100 \mathrm{~g}$ 의 구리 함량을 보인다는 Hunt(1990)의 보고와 비교해서 소스 종류에 따른 구리 함량은 큰 차이를 보였다. 우리나라 성인 남녀의 구리의 권장섭취량은 1 일 $0.8 \mathrm{mg}$ 으 로 제정되어 있다. 26종 소스 중 구리 최대함유량이 $145.74 \pm 11.52 \mu \mathrm{g} / 100 \mathrm{~g}$ 으로 1 일 권장섭취량에 비해서는 구리 함유량이 낮은 편임을 알 수 있었다.

그리고 26 종의 소스류 중 백설 데리야끼소스 및 백설 돈카츠소스에서는 아연 함량이 검출되지 않았고, 그 외 소스류에서는 $11.70-451.10 \mu \mathrm{g} / 100 \mathrm{~g}$ 으로 소스 종류에 따 라 큰 아연 함량 차이를 나타내었다. 그 중 곤드레나물밥 양념장 및 강된장 덮밥소스는 $448.57-451.10 \mu \mathrm{g} / 100 \mathrm{~g}$ 의 유의적으로 가장 높은 아연 함량을 나타내었고, 토마토 스파게티소스, 주부초밥왕 새콤달콤 유부초밥 식초양념, 타이 스위트 칠리소스는 $11.70-36.83 \mu \mathrm{g} / 100 \mathrm{~g}$ 의 유의적
으로 낮은 아연 함량을 나타내었다. 또한, 시판 토마토스파 게티소스의 아연 함량의 경우 볼로냐스파게티 토마토스 파게티소스 $372.03 \pm 15.59 \mu \mathrm{g} / 100 \mathrm{~g}$, 프레스코 토마토스파 게티소스 $94.52 \pm 33.24 \mu \mathrm{g} / 100 \mathrm{~g}$ 그리고 토마토스파게티소 스 $11.70 \pm 0.96 \mu \mathrm{g} / 100 \mathrm{~g}$ 으로 제조업체에 따라 큰 차이를 보였고, 시판 소스류 26종 중 주부초밥왕 새콤달콤 유부초 밥 식초양념과 고메레시피 사골육수 부대찌개 양념을 제 외한 양념이라는 제품명으로 시판되는 제품이 높은 아연 함량을 나타내었다. 19-49세 성인 남녀의 아연 1 일 권장섭 취량은 각각 $10 \mathrm{mg}$ 및 $8 \mathrm{mg}$ 으로(The Korean Nutrition Society, 2015), 26종 소스 중 아연 최대함유량이 451.10 \pm 9.14 $\mu \mathrm{g} / 100 \mathrm{~g}$ 이므로 1 일 권장섭취량에 비해서는 아연 함유량 이 아주 낮았다.

소스류의 셀레늄 함량은 $1.51-156.78 \mu \mathrm{g} / 100 \mathrm{~g}$ 으로 소 스 종류에 따라 셀레늄 함량이 큰 차이를 보였고, 특히 10 종의 무기질 중에서 소스 내 셀레늄 함량이 가장 낮았다. 소스류 중 곤드레나물밥 양념장에서 셀레늄 함량이 $156.78 \pm 12.55 \mu \mathrm{g} / 100 \mathrm{~g}$ 으로 유의적으로 가장 높은 함량을 나타내었고, 콩닥콩닥애 간장소스(무침, 조림용)에서도 $80.70 \pm 3.59 \mu \mathrm{g} / 100 \mathrm{~g}$ 의 유의적으로 높은 셀레늄 함량을 나타내었다. 그 외 소스류에서는 $1.51-27.06 \mu \mathrm{g} / 100 \mathrm{~g}$ 의 셀레늄 함량을 보였다. 즉, 곤드레나물밥 양념장 및 콩닥콩 닥애 간장소스(무침, 조림용)는 다른 소스류에 비해 6배 11 배 정도의 높은 셀레늄 함량을 나타냄을 알 수 있었다. 셀레늄은 글루타티온 과산화효소의 구성성분으로 폐암, 간암, 전립선암 등과 같은 암 발생 억제 및 암 예방 효과가 있는 미량 무기질로(Duffield-Lillico 등, 2003; Rayman, 2005), 셀레늄의 영양학적 중요성이 알려지고 있음에도 불구하고 우리나라 영양섭취기준 설정에 필요한 database 가 부족한 실정이므로, 우리나라에서 널리 소비되고 있는 소스류에 대한 셀레늄 함량에 대한 자료제공이 중요하다 고 하겠다.

\section{요 약}

본 연구에서는 26종 시판 소스류의 무기질 및 회분 함량 을 분석하였고, 무기질 중 $\mathrm{Na}, \mathrm{Ca}, \mathrm{K}, \mathrm{P}, \mathrm{Mg}, \mathrm{Fe}, \mathrm{Mn}, \mathrm{Zn}$ 및 $\mathrm{Cu}$ 은 ICP-OES로, $\mathrm{Se}$ 은 ICP-MS로 분석하였다. 소스류 의 회분 함량은 $1.08-12.79 \mathrm{~g} / 100 \mathrm{~g}$ 이었으며, 특히 곤드레 나물밥 양념장 $(12.79 \pm 0.02 \mathrm{~g} / 100 \mathrm{~g})$ 은 칼슘 및 구리 함량을 제외한 8 종의 무기질이 가장 높게 함유되어 유의적으로 가장 높은 회분 함량을 나타내었다. 소스류의 나트륨 함량 은 $272.68-4,336.56 \mathrm{mg} / 100 \mathrm{~g}$ 으로 곤드레나물밥 양념장 $(4,336.56 \pm 67.34 \mathrm{mg} / 100 \mathrm{~g})$ 이 유의적으로 가장 높은 함량을 보였고, 청정원 카레여왕 망고\&바나나 조리예에 맞춰 조 리한 카레소스 $(272.68 \pm 8.86 \mathrm{mg} / 100 \mathrm{~g})$ 는 유의적으로 가장 
낮은 나트륨 함량을 나타내었다. 칼슘 함량은 풀무원 생가 득 4가지 치즈크림 스파게티 크림소스(108.36 \pm 3.08 $\mathrm{mg} / 100 \mathrm{~g}$ )에서 유의적으로 가장 높은 함량을 나타내고, 그 외 소스류에서는 $5.93-43.64 \mathrm{mg} / 100 \mathrm{~g}$ 이었다. 칼륨 및 인 함량은 각각 $51.74-448.76 \mathrm{mg} / 100 \mathrm{~g}$ 및 $7.81-115.95$ $\mathrm{mg} / 100 \mathrm{~g}$ 이었으며, 그 중 곤드레나물밥 양념장에서 칼륨 $(370.94 \pm 9.44 \mathrm{mg} / 100 \mathrm{~g})$ 및 인 $(100.63 \pm 0.77 \mathrm{mg} / 100 \mathrm{~g})$ 의 함 량이 높았고, 주부초밥왕 새콤달콤 유부초밥 식초양념은 칼륨 $(51.74 \pm 8.13 \mathrm{mg} / 100 \mathrm{~g})$ 및 인 $(7.81 \pm 0.41 \mathrm{mg} / 100 \mathrm{~g})$ 함량 이 유의적으로 가장 낮았다. 소스류의 마그네슘 함량은 $2.69-74.45 \mathrm{mg} / 100 \mathrm{~g}$ 이었고, 아연 함량은 백설 데리야끼 소스 및 백설 돈카츠소스에서는 검출되지 않았고, 그 외 소스류에서는 $11.70-451.10 \mu \mathrm{g} / 100 \mathrm{~g}$ 이었다. 또한, 소스 내 철 $(2.14-1,759.02 \mu \mathrm{g} / 100 \mathrm{~g})$, 망간(7.57-609.21 $\mu \mathrm{g} / 100$ $\mathrm{g})$, 구리 $(3.38$ - $145.74 \mu \mathrm{g} / 100 \mathrm{~g})$ 및 셀레늄 $(1.51-156.78$ $\mu \mathrm{g} / 100 \mathrm{~g}$ ) 함량은 소스 종류에 따라 큰 차이를 나타내었다. 따라서 본 연구는 국내에서 유통되는 소스류에 대한 무기 질 및 회분 함량 정보를 제공하고, 나아가 국가식품영양성 분 데이터베이스 구축의 기초자료로 활용될 것으로 생각 되었다.

\section{감사의 글}

본 연구는 2018년도 식품의약품안전처의 연구개발비 (17162MFDS082)로 수행되었으며 이에 감사드립니다.

\section{Conflict of interests}

The authors declare no potential conflict of interest.

\section{ORCID}

Sam-Pin Lee https://orcid.org/0000-0001-9413-2482

\section{References}

Blaustein MP, Hamlyn JM. Role of nutriture factor in essential hypertension: An hypothesis. Ann Intern Med, 98, 785-792 (1983)

Choi BY, Nam HK, Hwang YJ, Kim SH. Effect of high calcium diet on the zinc and copper balance in Korean female adolescents. J Korean Soc Food Sci Nutr, 30, 894-899 (2001)

Choi SK. Theory and Practice of Sauces. Hyungsul Publishing Co, Seoul, Korea, p 1-30 (1997)

Choi SK. Theory and Practices of Sources. Hyungsul
Publishing Co, Seoul, Korea, p 10-30 (2008)

Choi SK, Kim SH, Choi EH, Shin KY, Lee JH, Lee MS. Quality and sensory characteristics of Gochujang sauce by degree of hot taste. Korean J Culinary Res, 16, 268-277 (2010)

Choi Y, Oh JH, Bae IY, Cho EK, Kwon DJ, Park HW, Yoon S. Changes in quality characteristics of seasoned soy sauce treated with superheated steam and high hydrostatic pressure during cold storage. Korean J Food Cookery Sci, 29, 387-398 (2013)

Chun OK, Han SH. A study on the contents of inorganic compounds in soft drinks. J Food Hyg Saf, 15, 344-350 (2000)

Duffield-Lillico AJ, Dalkin BL, Reid ME, Turnbull BW, Slate EH, Jacobs ET, Marshall JR, Clark LC. Selenium supplementation, baseline plasma selenium status and incidence of prostate cancer: an analysis of the complete treatment period of the nutritional prevention of cancer trial. BJU Int, 91, 608-612 (2003)

FAFFDC. 2018 Processed food segment market status report. Source market. Korea Agriculture \& Fishery Food Distribution Corporation, p 58-75 (2018)

Gary R. Source Book of Flavors. 2nd ed, Chapman and Hall, New York, USA, p 626-654 (1999)

Greger JL. Dietary standards for manganese: Overlap between nutritional and toxicological studies. J Nutr, 128, 368-371 (1998)

Haek AC, Lemmens AG, Mullink JW, Beynen AC. Influence of dietary $\mathrm{Ca}$ : $\mathrm{P}$ ratio in mineral excretion and nephrocalcinosis in female rats. J Nutr, 118, 1210-1216 (1988)

Hunt SM, Groff JL. Advanced Nutrition and Human Metabolism. West Publishing Co, St Paul, MO, p 306-310 (1990)

Hwang IS, Jang MR, Kim OH, Lee SD, Park YA, Choi BC, Lee KA, Kim LL, Kim DK, Jung AH, Oh YH, Kim $\mathrm{JH}$, Jung K. Contents of sodium, potassium and foodborne pathogens contamination of slide dishes distributed in Seoul area. J Food Hyg Saf, 32, 35-41 (2017)

Jablonska E, Gromadzinska J, Sobala W, Reszka E, Wasowicz W. Lung cancer risk associated with selenium status is modified in smoking individuals by Sep15 polymorphism. Eur J Nutr, 47, 47-54 (2008)

Kang KT, Heu MS, Kim JS. Development of spaghetti sauce with oyster. J Korean Soc Food Sci Nutr, 36, 93-99 (2007)

Kenneth TF. Spices, Condiments and Seasonings. Chapman 
and Hall, New York, USA, p 289-389 (1990)

Kim ES, Yim GS, Choi KS, Jeong GH, Lee MY, Ryu SH, Yoon EK. A guideline for sodium reduction of processed foods. Food Sci Ind, 49, 8-17 (2016)

Kim MG, Kim YS, Kim YS, Lee SB, Ryu KS, Yoon MH, Lee JB. A study on the content of minerals in fortified food. J Fd Hyg Safety, 29, 99-104 (2014)

$\mathrm{Kim} \mathrm{OH}$, Kim ES. A study on the mineral content of calcium-fortified foods in Korea. J Korean Soc Food Sci Nutr, 32, 96-101 (2003)

Kirchessner M, Spoerl R, Scneider UA, Kirchge Bner M. Trace element metabolism in man and animal-3. ATW, Freising-Weihenstephan, West Germany, p 440 (1978)

Korea Centers for Disease Control and Prevention (MOHW \& KCDC). Korea Health Statistics 2014: Korea National Health and Nutrition Examination Survey (KNHANES VI-2). Seoul (2015)

Lee EJ, Mun KC. Globalization of Korean cuisine through Korean sauces-focusing on the success of world wide sauces. Korean J Culinary Res, 18, 108-120 (2012)

Lee MK. Sodium intake of students and sodium content of processed foods used in the school meal service. MS Thesis, Wonkwang University, Korea, p 11-18 (2008)

Lee SK, Chang EJ, Choi JC, Bahn KN, Kim MH. Current assessment of sodium and potassium intakes in elementary and middle school students through school meals. Korean J Food Sci Technol, 42, 578-585 (2010)

Lim HJ. A study on the food intake, sodium and potassium intakes and urinary excretion of preschool children in Pusan. Korean J Nutr, 33, 647-659 (2000)

Mena I. Disorders of Mineral Metabolism. In: Bronner FL,
Coburn JW (Editors), Academic Press, New York, USA, p 230-270 (1981)

Ministry of Health and Welfare of Korea, Korea Centers for Disease Control and Prevention (MOHW \& KCDC). Korea Health Statistics 2016: Korea National Health and Nutrition Examination Survey (KNHANES VII-1). Seoul, Ministry of Health and Welfare of Korea (2016)

NIAS. Maintenance of nutrient database and analysis of minerals and fatty acid for national standard food composition table (9th revision). Final Report of National Institute of Agricultural Sciences, TRKO201800043137 (2018)

Park SH, Song WJ, Chun JY. Analysis of cholesterol, retinol, beta-carotene and vitamin $\mathrm{E}$ contents in regional food south Korea. J Korean Soc Food Sci Nutr, 47, 429-439 (2018)

Rayman MP. Selenium in cancer prevention: A review of the evidence and mechanism of action. Proc Nutr Soc, 64, 527-542 (2005)

Sandstrom B, Davidsson L, Eriksson R, Alpsten M, Bogentoft C. Retention of selenium (75Se), Zinc (65Zn) and manganese $(54 \mathrm{Mn})$ in humans after intake of a labelled vitamin and mineral supplement. J Trace Elem Electrolytes Health Dis, 1, 33-38 (1987)

Shahidi F, Parliment TH, Mcromine RJ, Ho CT. Flavor of cooked meats. In: Thermal Generation of Aroma. ACS Symposium Series 409, Washington, DC, USA, p 131-154 (1989)

The Korean Nutrition Society. Dietary Reference Intakes for Koreans, Ministry of Health and Welfare, p 48, 58, 60 (2015) 